\title{
Les espaces verts en zone urbaine et périurbaine de Kinshasa en République Démocratique du Congo
}

K.R. Sambieni, Y. Useni Sikuzani, S. Cabala Kaleba, A. Biloso Moyene, F. Munyemba Kankumbi, R. Occhiuto \& J. Bogaert

\section{K.R. Sambieni :}

\section{Y. Useni Sikuzani :}

\section{S. Cabala Kaleba :}

\section{A. Biloso Moyene :}

F. Munyemba Kankumbi :

\section{R. Occhiuto :}

\section{J. Bogaert :}

DOI: $\underline{10.25518 / 2295-8010.648}$

\section{Résumé :}

La présente étude évalue les caractéristiques des espaces verts soumis à la périurbanisation à Kinshasa en République Démocratique du Congo à travers leur typologie, leur structure spatiale, leur composition végétale, leur mode de gestion, leur état d'entretien et leurs services écosystémiques potentiels. L'analyse est basée sur un échantillon aléatoire de 87 espaces verts enregistrés dans la zone urbaine et périurbaine de la ville de Kinshasa à partir de tests exacts de Fisher et des analyses de variance. Les résultats indiquent que les espaces verts présentent des caractéristiques similaires le long du gradient d'urbanisation avec une diversité végétale relativement plus élevée en zone périurbaine. La zone périurbaine se démarque par la présence de jardins/potagers tandis que la zone urbaine offre plutôt des espaces encadrés par le bâti (cours) qui, dans la plupart des cas, sont à usage collectif. Quant aux services écosystémiques attendus, ils présentent peu de variation le long du gradient urbain-rural. Néanmoins, les services écosystémiques dominants sont moins liés à l'amélioration de la qualité environnementale des milieux habités qu’aux besoins économiques et/ou socio-culturels des populations. Il s'avère nécessaire d'établir un réseau vert multifonctionnel à travers le maintien et l'aménagement d'espaces verts adaptés aussi bien à la demande sociale qu'aux défis environnementaux de la ville.

\section{Abstract : \\ Green Spaces in the Urban and Peri-urban Area of Kinshasa in the Democratic Republic of the Congo.}

This study evaluates the characteristics of green spaces subject to peri-urbanization in Kinshasa. It analyzes their typology, spatial pattern, vegetation, management, state of maintenance and 
Les espaces verts en zone urbaine et périurbaine de Kinshasa en République Dé...

potential ecosystem services. The analysis is based on a random sample of 87 green spaces situated in urban and peri-urban areas of the city and is mainly based on Fisher exact tests and analysis of variance. Results show that the studied green spaces have similar characteristics along the urbanization gradient with a relatively high plant species diversity in peri-urban areas. Peri-urban areas stand out for gardens while green spaces with collective courts characterize most urban areas. As for the expected ecosystem services, they show little variation along the urban-rural gradient. Nevertheless, the dominant ecosystem services are less related to the improvement of the environmental quality of inhabited areas than to economic and or sociocultural population needs. It seems necessary to establish a multifunctional green network through the maintenance and development of green spaces responding to the social demand and environmental challenges of the city.

Keywords : Green infrastructure, Peri-urban space, Ecosystem service, Kinshasa, Ecology

PDF généré automatiquement le 2020-06-26 16:38:12

Url de l'article : https://popups.uliege.be:443/2295-8010/index.php?id=648 